\title{
The Contemporary Confirmation of the Marx's World Communication Theory on the Construction of the Community with a Shared Future for Mankind
}

\author{
WEI WU
}

\author{
School of Marxism, Central University of Finance and Economics \\ wuwei9780@163.com
}

\begin{abstract}
How can we understand Marx's World Communication Theory in the modern era of globalization? What is relation between Marx's World Communication Theory and a Community with a Shared Future for Mankind (CSFM)? And how to build community with a shared future for mankind? In this paper, the author defines the connotation of Marx's World Communication Theory, explaining it as an important part of Historical Materialism shows the subject of communication breaks through geographical restrictions and turns to world-wide communication. With the globalization development tendency, the CSFM is the inheritance and development of Marx's World Communication Theory. The study sheds light on the intrinsic identity in the aspects of the philosophical basis, connotation and value proposition. About the construction of the CSFM, the author suggests that China should build it in three interconnected aspects: follow the globalization, strengthen the international relationship and insist on the direction of human civilization communication. For the further study about the CSFM, this paper contributes to the theoretical potential for its construction.
\end{abstract}

Keywords: Marxism; Marxist theory; world communication theory; a community with a shared future for mankind

\section{INTRODUCTION}

Since the setting up of the world market in the late nineteenth century, communications among different people, nations and countries began around the world. Marx investigated the capitalist society and human society development, stated the theory of world-wide production and world communication. Marx World Communication Theory is vital to Marxist theory. With the globalization developing, there are problems seriously affecting the development of countries around the world. Meanwhile, China scrambled to send in help, proposed to build a concept of a Community with a Shared Future for Mankind. In this paper, the author attempts to study the relationship of Marx's World Communication Theory and the CSFM. The findings should make a contribution to the field of the construction of the CSFM. The paper is structured into four parts. First, it will define the connotation of the Marx's world communication theory. Second, it will discuss the relation between Marx's World Communication Theory and the CSFM In part three, it will look at how to build the CSFM nowadays. Finally, a conclusion draws out the main contributions and implications of this study for understanding and constructing the CSFM.

\section{THE CONNOTATION OF THE MARX'S WORLD COMMUNICATION THEORY}

\subsection{The country has become the subject of world communication, and the scope of communication breaks through geographical restrictions and shifts to the world-wide communication}

As stated by Marx, the relationship of subjects has shifted from "the past local and national self-sufficiency and closed-door self-sufficiency" $[1] 404$ to be open, interdependent and cooperative in world communication. Marx pointed out that the communication between individuals is the prerequisite for producing. Meanwhile, interpersonal communication promotes the development of the productive forces, and communication form are 
determined by productivity. ${ }^{[1]}{ }^{147}$ With the continuous improvement of productivity, the needs for exchanges and cooperation between countries in the world are increasing.

\subsection{World communication includes material communication and spiritual communication and material communication is a prerequisite for spiritual communication}

Marx pointed out that because the bourgeoisie expanded markets around the world, the production and consumption had broken the constraints of space. [1]404 Specifically, the world market has broken the selfsufficiency and closed state of all nations, then the material production made around the world. With material communication continuing to develop, the spiritual and cultural communications of different nations have emerged. In the process of continuous material and spiritual communication, the economic and culture of different nations and countries have been greatly developing, which jointly promote the development of productive forces.

\subsection{The forms of world communication can be divided into two forms: peaceful communication and violent communication}

According to Marx, peaceful communication includes international trade, world markets and so on. Moreover, Commercial trade is a greatly important manifestation of peaceful communication. And forms of violence include war, colonial aggression and so on. As Marx stated "for the barbaric conqueror nation... the war itself is still a regular form of communication" "2]26, which illustrates violence communication is based on a low level of productivity. With the general development of productivity, peaceful communication will eventually replace the violent communication.

\section{COMMUNITY WITH A SHARED FUTURE FOR MANKIND: INHERITING AND DEVELOPING THE MARX'S WORLD COMMUNICATION THEORY}

\subsection{Marx's theory of world communication and the CSFM jointly build on historical materialism as the philosophical basis}

Marx's World Communication Theory is based on historical materialism. Historical Materialism is the Marxist theory about investigating human production and lifestyles, summarizing the general laws of human social development. As Marx stated, social existence determines social consciousness, implying practice determines communication theory. By contrast, German classical philosophy thinks that communication is the result of human spiritual thinking activities. On the basis of inheriting and criticizing German classical philosophy and relying on the method of Historical Materialism, Marx made it clear that the value of the theory of communication is based on the actual material foundation, and pointed out it is an important force for the development of human history. In this sense, human communication had broken through the previous backwardness and isolation due to development of practice. With the new stage coming, the transformation of human production and lifestyle determines the transformation of the way of communication.

The CSFM is the theoretical innovation of Historical Materialism in the new era, and a major manifestation of Marxist theory of world communication in contemporary China. Construction of the CSFM is the actual demand of today's globalization and the inevitable result of historical development. Xi Jinping pointed out that with development of globalization, the international countries should be prepared to actively participate in international cooperation to build shared interests and promote the construction of a community with a shared future for mankind. ${ }^{[4]}$

\subsection{Marx's World Communication Theory and the CSFM maintain internal unity in their connotations}

Marx's World Communication Theory has profound connotations, revealing the relationship among communication, production, and community. Marx pointed out that, only when people interact with each other and participate in common activities can the production be conducted smoothly. Simultaneously, the communication relationship also has an important impact on future production practice. As state by Marx, "there will be their influence on the natural world, and there will be production." [5] 486 it provides that production practice is not only the basis for the generation of communication but also the purpose and result of the development of communication. To purse advanced productivity, people form as a community to engage in practice. Community as a form of communication is the inevitable result of communication, and it is also to promote higher-level communication activities. In different historical periods, the level of productivity development determines different forms of communication. In order to adapt to more developed productivity, a new form of communication is needed that is more conducive to promoting the progress of production activities. That means advanced communication form will eventually replace the old and backward one. ${ }^{[3] 81}$ This also means that it needs a new community adapting to the development level of productivity, which can further promote the development of production. 
The CSFM has enriched and developed the connotation of Marx's World Communication Theory. $\mathrm{Xi}$ Jinping pointed out in the report of the 19th National Congress: "People of all countries work together to build a community with a shared future for mankind, and build a world of lasting peace, universal security, common prosperity, openness, tolerance, cleanliness and beauty" [6]. Therefore, the CSFM fully demonstrates what it tries to build is a community that pursues the peaceful development of the global environment, the common prosperity and development of the world economy, the openness and inclusiveness of civilizations of all nations. Nowadays, various countries have be facing with conflicts and contradictions from the development of globalization, such as unbalanced economic development, cultural shocks, violent conflicts, and ecological pollution in the world. So, the reform of the pattern of international communication is important. That is, the CSFM is a new pattern of world communication, and it answers the problems faced by countries around the world and puts forward solutions.

\subsection{Marx's theory of world communication and the CSFM pursue the free development of human beings in terms of value proposition}

As stated by Marx, the general development of productivity is the power of the general communication. On the one hand, "there are people without property"[1] 166 will come with world communication, that means the elimination of private ownership and the elimination of capital exploitation. The capitalist pattern of production leads to human alienation. Though eliminating the private ownership, people will find themselves and get free. On the other hand, individuals who were previously restricted by regions have broken through the constraints of this space. In this sense, individuals truly gain the ability to develop themselves and realize their own free development. This also shows that Marx's theory of world communication points to the ultimate state of human society to realize the free and comprehensive development of human beings.

The CSFM focuses on the common interests of all mankind, whose aim is to ultimately realize human freedom and the liberation of all mankind, rather than the interests of capitalism and individual country. Zhanxiu Cong pointed out, "The community with a shared future for mankind promotes the true value of all mankind in terms of value consensus."[7] Peace, development, fairness, justice, democracy, and freedom are the common values of all mankind, that draw out a picture that all countries and nations live together in a peaceful, secure, fair, just, democratic and free world, where nations are tolerant and integrated, individual interests and collective interests are coordinated and unified, there are no conflicts and contradictions, and harmonious coexistence between people and nature is achieved. It can be said that the common value of all mankind is to realize the liberation of mankind and realize the free development of individuals.

\section{THE CONTEMPORARY GUIDE OF THE CONSTRUCTION OF COMMUNITY WITH A SHARED FUTURE FOR MANKIND}

\subsection{Conform to the development trend of economic globalization}

This is the practice of Historical Materialism in the construction of the CSFM. Firstly, we should realize the importance of globalization and accept it. Globalization is an objective requirement for the development of social productive forces and an inevitable result of technological progress. [8]401-403 Following this, we should take an active part in globalization, and try to be in steps with globalization. Xi Jinping have repeatedly emphasized the importance of economic globalization, the construction of a community with a shared future for mankind must conform to the development trend of economic globalization. Finally, we need to strengthen coordination and improve governance, and promote the construction of an open, inclusive, inclusive, balanced, and win-win economic globalization. ${ }^{[8] 421}$

\subsection{Strengthen international cooperation}

Building a community with a shared future for mankind requires international cooperation. Marx criticized capitalism for aggression and plundering other nations, and he pointed out that the communicative activities carried out by capitalism are essentially a kind of "predation", At present, the world is facing multiple crises in nature, economy, politics, and society such as energy crisis, natural disasters, network security, terrorist organizations, economic crises, hegemonism, and unilateralism, which seriously threaten the survival and security of mankind. In Xi Jinping's speech at the World Economic Forum's Davos Agenda Dialogue on January 25, 2021, he pointed out all global problems faced by mankind cannot be solved by any country if it wants to fight alone. Action, global response, global cooperation. Facing global problems, all nations have become a "community", which requires people from all countries to face it together and create a peaceful and secure world pattern.

\subsection{Insist on the direction of human civilization exchanges as a whole}

Civilizations of different nationalities have been developed in the process of world exchanges, which in turn promotes the development of civilizations and the liberation of human society. Xi Jinping said, "China is an important representative of Eastern civilization, and Europe is the birthplace of Western civilization. Just as 
the Chinese love tea and the Belgians love beer, Tea and wine are not incompatible. You can drink a thousand cups of friends. If there is less, you can also taste tea and taste life." ${ }^{[8] 103}$ Chinese and Western civilizations are not mutually hostile relations, but mutual tolerance and mutual reference, but a different harmonious relationship. To build a community with a shared future for mankind, we must always grasp the direction of civilized exchanges, and on the basis of advocating selfconfidence in our own civilization, respect other nations' civilizations, and jointly build a colorful, equal and inclusive civilization concept.

\section{CONCLUSION}

The primary contribution of this paper has demonstrated Marx's World Communication Theory and the CSFM maintain unity in the philosophical logic, connotation and value proposition, which imply the confirmation of Marx's World Communication Theory on the construction of the CSFM. It is significant to regard Marx's World Communication as the guide. With the background of globalization, the international relationship needs a new pattern to guide it, that is the CSFM. Among the limited studies on Marx's World Communication Theory and the CSFM, the author explores the meaning of Marx's world communication theory by quoting and explaining the original source of Marx's classic, and observes the inner relationship between Marx's World Communication Theory and the CSFM. With the new reports of China government, the author tries to connect theory with practice to claim the contemporary confirmation of Marx's world communication theory on the construction of the CSFM. The research on the Marxist theory and the CSFM is popular in this filed. For future studies, the paper offers a possible lens to research the construction of the CSFM.

\section{REFERENCES}

[1] Marx K, Engels FV. (2012) The Selected Works of Marx and Engels (Volume 1). People's Publishing House, Beijing. (In Chinese)

[2] Marx K, Engels FV. (1960) The Complete Works of Marx and Engels (Volume 3). People's Publishing House, Beijing. (In Chinese)

[3] Tongfong Liu. (2018) The Original Contribution of Building a Community with a Shared Future for Mankind to Historical Materialism. Social Sciences in China., 7: 18-19. (In Chinese)

[4] Xi Jinping. (2018) Together in a boat to create a better future. People's Daily. (In Chinese)

[5] Marx K, Engels FV. (1960) The Complete Works of Marx and Engels (Volume 6). People's Publishing House, Beijing. (In Chinese)

[6] Xi Jinping. Decisive victory and victory. The 19th National Congress of the Communist Party of China, 58-59. (In Chinese)

[7] Zhanxiu Cong. (2016) The Community of Human Destiny: History, Reality and Implication. Theory and Reform, 03: 01. (In Chinese)

[8] Xi Jinping. (2018) On Persisting in Promoting the Construction of a Community with a Shared Future for Mankind. Central Literature Press, Beijing. (In Chinese) 